\title{
Eutrophication and endangered aquatic plants: an experimental study on Baldellia ranunculoides (L.) Parl. (Alismataceae)
}

\author{
Gregor Kozlowski · Sophie Vallelian
}

Received: 12 December 2008/Revised: 10 July 2009/Accepted: 21 July 2009/Published online: 5 August 2009

(C) Springer Science+Business Media B.V. 2009

\begin{abstract}
Anthropogenic enrichment of aquatic ecosystems is an increasingly common phenomenon, resulting from human population growth and the intensification of industrial and agricultural developments. Eutrophication has been considered to be one of the main causes of the decline of many aquatic plants. These observations, however, have rarely been supported by data or explored in detail using an experimental approach. Our experimental study demonstrates, for the first time, a strong direct negative influence of eutrophication on the performance of the endangered aquatic plant Baldellia ranunculoides s.str. (L.) Parl. (Alismataceae). Both morphological and reproductive traits were significantly affected by this phenomenon. Plants growing on eutrophic substrates were much smaller, possessed fewer and smaller leaves, and their biomass was on average half that of plants growing on a mesotrophic substrate. Additionally, plants growing on eutrophic substrates produced fewer inflorescences and flowers, and they
\end{abstract}

Handling editor: S. M. Thomaz

G. Kozlowski $(\bowtie)$

Department of Biology and Botanical Garden, University

of Fribourg, Chemin du Musée 10, 1700 Fribourg,

Switzerland

e-mail: gregor.kozlowski@unifr.ch

S. Vallelian

Department of Geosciences, University of Fribourg,

Chemin du Musée 4, 1700 Fribourg, Switzerland had a smaller number of achenes per capitulum. Consequently, they produced only $15 \%$ of the seeds produced by plants growing in non-eutrophic conditions. Thus, the chance of long-term subsistence of B. ranunculoides populations in strongly eutrophic habitats will be significantly reduced, and at the same time, the success of any new establishment of viable $B$. ranunculoides populations in such habitats will be highly restricted. Conservation efforts for B. ranunculoides, either of existing populations or in newly selected re-introduction sites, should start, therefore, with an assessment of the trophic level of those sites. On the other hand, due to its sensitivity to eutrophication, the presence of viable populations of B. ranunculoides can be used as an indicator of valuable aquatic habitats for oligotrophy-dependent organisms.

Keywords Aquatic macrophytes - Endangered species - Global change $\cdot$ Life traits $\cdot$ Nitrogen deposition

\section{Introduction}

In recent decades, the human-generated modification of natural habitats has reached an unprecedented level (Jenkins, 2003; Kareiva et al., 2007). In the future, the appropriation of natural resources for human needs will expose the environment to even 
more drastic changes (Sala et al., 2000; Foley et al., 2005). Aquatic organisms and their habitats are particularly affected by human-caused global change and its various facets (Carpenter et al., 1992; Sala et al., 2000; Cronk \& Fennessy, 2001; Malmquist \& Rundle, 2002; Egertson et al., 2004). In many regions, aquatic plants are among the most threatened groups of organisms (Preston \& Croft, 2001; Moser et al., 2002). The genus Baldellia is not an exception, as its taxa are threatened in the majority of European countries and have strongly declined throughout their area of distribution due to habitat destruction, fragmentation and other anthropogenic changes (Roelofs, 1983; Preston \& Croft, 2001; Jones, 2006; Kozlowski et al., 2008).

Baldellia species are morphologically very plastic and respond to changes in environmental conditions, and especially to nutritional and hydrological change, with adjustments to their growth and physiology (Kozlowski et al., 2008). This phenotypic plasticity is typical of many aquatic plants (Sculthorpe, 1967). Baldellia is one of several small genera of the exclusively aquatic plant family Alismataceae (Cook, 1990). Baldellia taxa are perennial, rooted water plants that grow in lakes, ponds and slow streams (Vuille, 1988; Preston \& Croft, 2001). There are only two generally recognized species in the genus: Baldellia ranunculoides (L.) Parl. [with two subspecies: B. ranunculoides subsp. ranunculoides and subsp. repens (Lam.) Á. et D. Löve], which is native to Europe and the Mediterranean, and Baldellia alpestris (Coss.) Carv. Vasc., which is endemic to the mountains of northern Portugal and northwest Spain (Cook, 1983; Kozlowski \& Matthies, 2009). The present study deals exclusively with $B$. ranunculoides s.str., an emblematic taxon in the majority of European countries and a candidate for conservation priority lists.

Baldellia ranunculoides shows a strong decline in practically all regions of its natural range and it is probably the most threatened taxon of the genus (Kozlowski et al., 2009). The last region to contain numerous populations and high abundance of this taxon is Ireland. In France, Portugal, Spain and the UK, the taxon is not threatened according to the published national red lists. It was clearly demonstrated, however, that the conservation status is underestimated in these countries. In Germany, Norway and Benelux, B. ranunculoides is endangered (EN). In Switzerland,
Italy and Croatia the taxon is critically endangered (CR). In certain regions of Europe the species is regionally extinct (RE, e.g. in Poland and Sicily) (IUCN, 2001; Kozlowski et al., 2009).

It is a taxon growing mainly in coastal regions of Western Europe and the Mediterranean (Meusel et al., 1992; de Bolos \& Vigo, 2003; Kozlowski et al., 2008). In Central and Western Europe, B. ranunculoides s.str. is a characteristic species of the alliance HydrocotyloBaldellion Tx. et Dierssen apud Dierssen 1957, in the class Littorelletea uniflorae Br.-Bl. et Tx. 1943 ex Westhoff, Dijk et Paschier 1946 (Pott, 1995; Schubert et al., 1995; Kozlowski \& Matthies, 2009). The class L. uniflorae includes plant communities on sites with alternating water level in meso- to oligotrophic, stagnant or slowly running water. The communities are bound to a mineral soil, which is usually not covered by organic material, and their species number is rather low (Schaminée \& Arts, 1992).

Eutrophication has been generally considered to be one of the main causes of decline of many aquatic communities containing Baldellia sp. (Schoof-van Pelt, 1973; Roelofs et al., 1984; Arts, 2002; Kennedy \& Murphy, 2004). Organic enrichment causes important changes and degradation of EN aquatic plant communities (Bobbink et al., 1998; Egertson et al., 2004). However, these observations and conclusions have rarely been supported with data or explored in detail with an experimental approach.

The main aims of our study were thus to (1) estimate the sensibility of $B$. ranunculoides s.str. to eutrophication, (2) define which morphological and/ or reproductive traits are the most affected by the eutrophication and (3) provide a basis for more effective conservation measures and restoration efforts.

\section{Materials and methods}

\section{Plant material}

Seeds of $B$. ranunculoides s.str. were obtained from (1) Botanical Garden Fribourg, Switzerland; (2) Botanical Garden Berlin-Dahlem; (3) Botanical Garden Nantes, France and (4) Botanical Garden Coimbra, Portugal. The seeds were collected from natural populations from Canton Vaud (Switzerland), Nordrhein-Westphalia (Germany), Loire Atlantique (France) and Beira 
Litoral (Portugal). These four regions cover the geographical range of the taxon in Western and Central Europe. For the experimental assessment, seeds of all four origins were pooled together to exclude any effect of a local adaptation.

\section{Substrate preparation}

Three types of substrates were used for the experimental assessment: (1) control substrate-representing a mesotrophic substrate composition of $B$. ranunculoides s.str. based on our successful ex situ cultures at the Botanical Garden Fribourg (unpublished data) and our previous work (Kozlowski \& Matthies, 2009). It was obtained by mixing the four parts of topsoil with one part of coarse sand $(0.5-1.0 \mathrm{~mm}$ of diameter). The final mixture contained $46 \%$ of dry matter, $17 \%$ of organic matter, with conductivity of $123 \mu \mathrm{S} / \mathrm{cm}$ and $\mathrm{pH} 7.0$; (2) Treatment 1 (T1) -addition of $5 \mathrm{~g}$ of Hato ${ }^{\circledR}$ organic NPK fertilizer (Hauert HBG Dünger AG, Grossaffoltern, Switzerland) per $1 \mathrm{~kg}$ of the control substrate; Treatment 2 (T2) - addition of $10 \mathrm{~g}$ of Hato ${ }^{\circledR}$ per $1 \mathrm{~kg}$ of the control substrate. According to the manufacturer's indication, $5 \mathrm{~g}$ of Hato ${ }^{\circledR}$ fertilizer contains $400 \mathrm{mg}$ of total N, $200 \mathrm{mg}$ of $\mathrm{P}_{2} \mathrm{O}_{5}, 400 \mathrm{mg}$ of $\mathrm{K}_{2} \mathrm{O}, 75 \mathrm{mg}$ of $\mathrm{Mg}^{2+}$ and ca. $13 \mathrm{mg}$ of $\mathrm{Bo}, \mathrm{Cu}, \mathrm{Fe}, \mathrm{Mn}, \mathrm{Mo}$ and $\mathrm{Zn}$ (taken together).

\section{Experimental design}

For germination tests, we sowed 25 Baldellia seeds into $20 \times 20 \times 15 \mathrm{~cm}$ pots filled with substrate. Pots were placed in containers filled with water and, thus, maintained all the time under semi-aquatic conditions (substrate stayed constantly wet). Twenty pots were sowed for each treatment (Control, T1 and T2), giving a total of 500 seeds per treatment. After germination, 100 seedlings from each of the three different treatments were chosen randomly and grown until reaching maturity for 4 months under the same conditions in a greenhouse. After that, the following morphological and reproductive traits were assessed (see Fig. 1): the height of the plant, the number of leaves per plant, the length and width of all leaves, the number of pseudowhorls per plant, the number of flowers per pseudowhorl, and the achene number per capitulum. At the end of the 4 months, all plants were harvested (whole plant with roots), then oven-dried at $60^{\circ} \mathrm{C}$ for $48 \mathrm{~h}$ and weighed. The treatments were compared by

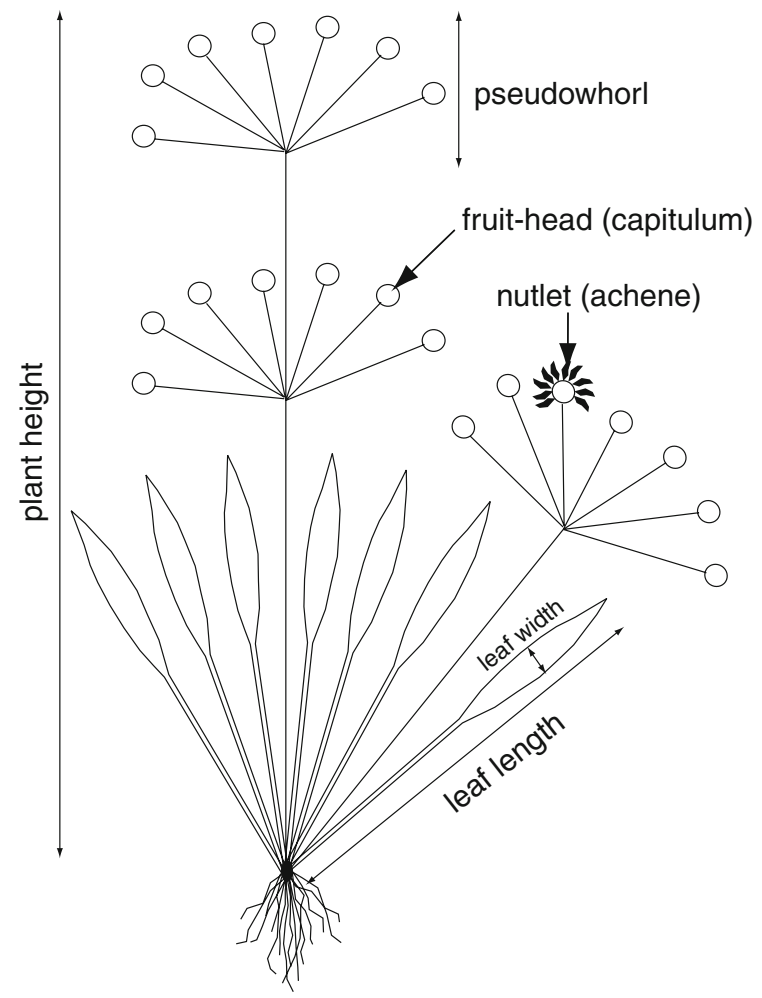

Fig. 1 Schematic representation of the morphological traits of B. ranunculoides s.str. measured during the eutrophication experiments

Kruskal-Wallis one-way analyses of variance, with $P$ values calculated by the Monte-Carlo permutation test available in SPSS 12.0 (10 000 runs). Statistically significant differences were defined at the level $P<0.05$.

\section{Results}

Figure 2 shows the effect of eutrophication on the morphology and reproductive traits of $B$. ranunculoides. For the majority of traits investigated, the difference between treatments was highly significant (the only exception was germination ratio, with $P=0.520$ ). After 4 months, mature plants growing on eutrophied substrates (T2 treatment) were much smaller (mean: $2.8 \mathrm{~cm}$ vs. $9.7 \mathrm{~cm}$ for control plants), possessed fewer leaves per plant (mean: 9.6 vs. 21.0), and the leaves were narrower and shorter (means: $6.5 \times$ $0.4 \mathrm{~cm}$ vs. $9.8 \times 0.6 \mathrm{~cm}$ for control plants) (see Fig. 2a, d, e, f). Consequently, the biomass of plants 
growing on eutrophic substrates was, on average, almost half that of plants grown on the control substrate (mean: $3.0 \mathrm{~g}$ for plants with T2 treatment vs. $5.5 \mathrm{~g}$ for plants on control substrate, Fig. 2c). Additionally, plants growing on $\mathrm{T} 2$ eutrophied substrates produced fewer pseudowhorls in their inflorescence (mean: 1.2 vs. 2.3 for control plants), which additionally developed fewer flowers (only three flowers per pseudowhorl vs. seven flowers in control plants) (Fig. 2g, h). They also produced, although less significantly $(P=0.025)$, a smaller number of achenes per capitulum (Fig. 2i). The

Fig. 2 Variation of $B$. ranunculoides s.str. morphological and reproductive traits under different eutrophication treatments. Box plots indicate the median and the 25 th and 75 th percentiles of the measured parameter. Whiskers indicate the upper and lower inner fence, circles are outliers. $P$ values for the differences among the treatments are results of Kruskal-Wallis one-wayANOVAs with MonteCarlo permutation tests (10,000 runs). Treatments: $C$ control mesotrophic conditions; $T 1$ eutrophication $(5 \mathrm{~g}$ of fertilizer $/ \mathrm{kg}$ of control substrate); T2 strong eutrophication $(10 \mathrm{~g}$ of fertilizer $/ \mathrm{kg}$ of control substrate). For more details, see Materials and methods section
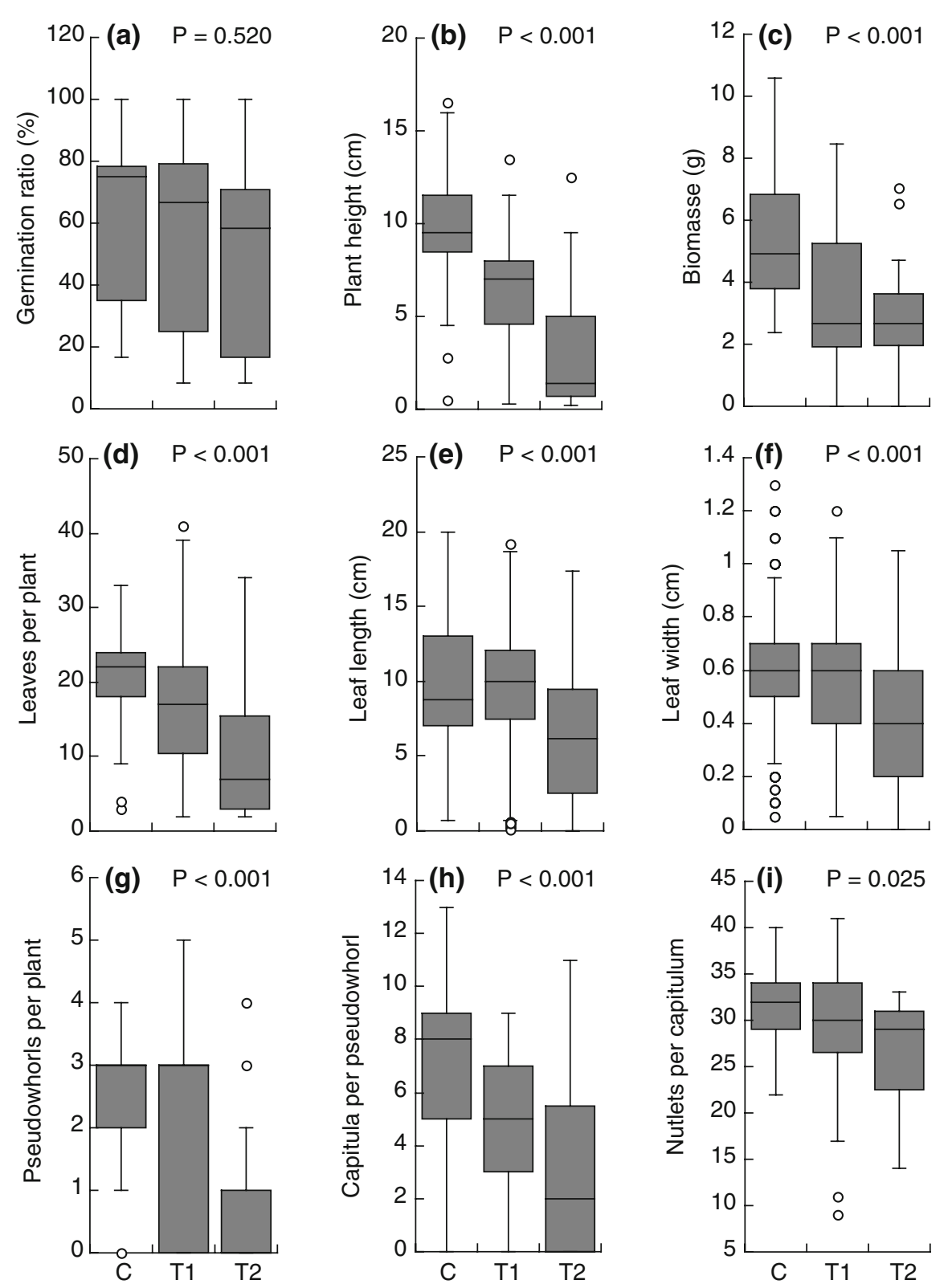

moderate eutrophication treatment (T1) had an intermediate effect on the growth and reproduction of $B$. ranunculoides (except for the leaf dimensions; Fig. 2e, f).

\section{Discussion}

Anthropogenic enrichment of aquatic ecosystems is an increasingly common phenomenon, resulting from human population growth and the intensification of 
industrial and agricultural developments (Thomas \& Daldorph, 1994). The importance of eutrophication in the decline of Baldellia species as well as other water plants has been stressed by several previous studies (Roelofs, 1983; Willby \& Eaton, 1993; Brouwer \& Roelofs, 2001; Kozlowski \& Matthies, 2009). However, many of those authors proposed that the eutrophication is rather indirectly responsible for this decline by favoring fast-growing species (Bobbink et al., 1998; Greulich et al., 2000). Our experimental study demonstrates for the first time a strong direct negative influence of eutrophication on the performance of the endangered B. ranunculoides. Both morphological and reproductive traits were significantly affected. The only exception to this effects was the germination ratio, indicating that B. ranunculoides is able to germinate on a broad spectrum of substrates (Fig. 2a). However, plants germinating in water bodies with high eutrophication will stay smaller, enhancing the probability that they will be out-competed by other co-occurring plants. Additionally, the reproduction of such plants will be strongly reduced. According to our results, an average plant growing on non-eutrophic substrate produces 2.3 pseudowhorls, ca. 16.5 flowers with 32 achenes per flower, and thus will produce ca. 520 seeds. In contrast, a single plant growing on a highly eutrophic substrate produces on average only one pseudowhorl with 3 flowers and 27 achenes per flower, thus producing only ca. 80 seeds (Fig. $2 \mathrm{~g}$, h, i). Thus, we conclude that $B$. ranunculoides plants growing in water bodies with high eutrophication will produce ca. $15 \%$ as many seeds as plants growing in noneutrophied conditions. In consequence, the chance of long-term subsistence of $B$. ranunculoides populations in strongly eutrophied habitats will be significantly reduced and any new establishment of viable B. ranunculoides populations in such habitats will be highly restricted. The potential mechanisms behind this unsuccessful performance of $B$. ranunculoides in eutrophic habitats remain unknown and need further investigations. It was demonstrated that $B$. ranunculoides reacts negatively to higher ammonium ion $\left(\mathrm{NH}_{4}{ }^{+}\right)$concentrations (Smolders et al., 2002). The nitrogen and/or ammonium toxicity might, therefore, play an important role in such high sensitivity to eutrophication.

Our results confirm the previous observations that the genus Baldellia is physiologically and ecologically highly specialized for oligotrophic-exposed littoral habitats with low biomass and low concurrence, making it an extremely sensitive taxon to any anthropogenic changes (Preston \& Croft, 2001; Kozlowski \& Matthies, 2009). Several other taxa of the exclusively aquatic family Alismataceae, e.g. Luronium natans (L.) Raf., show the same specialization (Willby \& Eaton, 1993; Szankowski \& Klosowski, 2001). Our results also confirm our previous observations that $B$. ranunculoides s.str. prefers oligotrophic sites with lower $\mathrm{N}$ concentrations compared to two other Baldellia taxa (B. ranunculoides subsp. repens and B. alpestris) (Kozlowski \& Matthies, 2009).

Baldellia ranunculoides belongs to the so-called Littorelletean and Isoetid species and is often accompanied by other rare and EN plants, e.g. Littorella uniflora (L.) Asch., Anagallis tenella (L.) L., Apium inundatum (L.) Rchb. f., Isoëtes spp. (Kozlowski et al., 2008). Thus, the presence of morphologically well-developed plants of B. ranunculoides can be used as an indicator of valuable aquatic habitats and sites with high conservation value for other oligotrophy-dependent organisms.

\section{Conclusions}

Our study clearly demonstrates that $B$. ranunculoides is adapted to low-fertility sites and is very sensitive to the eutrophication of its habitats. Although able to germinate even on heavily eutrophied substrates, it will produce in such conditions only dwarf forms with drastically reduced generative reproduction and vegetative growth. In natural conditions, such plants are not able to compete with other plants adapted to eutrophic habitats. Furthermore, in strongly eutrophic water bodies, the species will not be able to create new populations or persist for a long time, even if it still possesses shallow inundated and regularly exposed shore fragments with low plant cover. Thus, conservation efforts for $B$. ranunculoides, either of existing populations or in newly selected re-introduction sites, should start with the assessment of their trophic level. In order to maintain $B$. ranunculoides for a long time in a eutrophic water body, artificial disturbances must be performed almost every year-an extremely costly measure. On the other hand, due to its sensitivity to eutrophication, the presence of self-sustaining viable populations of $B$. ranunculoides can be used as an 
indicator of the intermediate nutrient concentrations, and thus of valuable aquatic habitats for oligotrophydependent organisms.

Acknowledgements We would like to thank Benoît Clement and Susanne Bollinger from the Botanical Garden of the University of Fribourg (Switzerland) as well as Françoise Cudré-Mauroux for their advice and support during the experimental work and manuscript preparation. We are much indebted to the Franklinia Foundation for its engagement and valuable support. We are very grateful to Christian Clerc (GEG Champ-Pittet, Switzerland) and to the Botanical Gardens of Coimbra (Portugal), Berlin-Dahlem (Germany) and Nantes (France) for seed collections.

\section{References}

Arts, G. H. P., 2002. Deterioration of Atlantic soft water macrophyte communities by acidification, eutrophication and alkalinization. Aquatic Botany 73: 373-393.

Bobbink, R., M. Hornung \& J. G. M. Roelofs, 1998. The effects of air-borne nitrogen pollutants on species diversity and semi-natural European vegetation. Journal of Ecology 86: 717-738.

Brouwer, E. \& J. G. M. Roelofs, 2001. Degraded softwater lakes: possibilities for restoration. Restoration Ecology 9: 155-166.

Carpenter, S. R., S. G. Fisher, N. B. Grimm \& J. F. Kitchell, 1992. Global change and freshwater ecosystems. Annual Review of Ecology and Systematics 23: 119-139.

Cook, C. D. K., 1983. Aquatic plants endemic to Europe and the Mediterranean. Botanische Jahrbücher für Systematik 103: 539-582.

Cook, C. D. K., 1990. Aquatic Plant Book. SPB Academic Publishing, The Hague.

Cronk, J. K. \& M. S. Fennessy, 2001. Water Plants: Biology and Ecology. Lewis Publishers, Boca Raton.

de Bolos, O. \& J. Vigo, 2003. Flora dels Paisos Catalans, Vol. IV. Barcino S.A., Barcelona.

Egertson, C. J., J. A. Kopaska \& J. A. Downing, 2004. A century of change in macrophyte abundance and composition in response to agricultural eutrophication. Hydrobiologia 524: 145-156.

Foley, J. A., R. DeFries, G. P. Asner, C. Barford, G. Bonan, S. R. Carpenter, F. S. Chapin, M. T. Coe, G. C. Daily, H. K. Gibbs, J. H. Helkowski, T. Holloway, E. A. Howard, C. J. Kucharik, C. Monfreda, J. A. Patz, I. C. Prentice, N. Ramankutty \& P. K. Snyder, 2005. Global consequences of land use. Science 309: 570-573.

Greulich, S., G. C. Bornette, C. Amoros \& J. G. M. Roelofs, 2000. Investigation of fundamental niche of rare species: an experiment on establishment of Luronium natans. Aquatic Botany 66: 209-224.

IUCN, 2001. IUCN Red List categories and criteria: version 3.1. Species Survival Commission, IUCN, Gland, Switzerland, and Cambridge, UK.

Jenkins, M., 2003. Prospects for biodiversity. Science 302: 1175-1177.
Jones, R. A., 2006. Creeping water-plantain (Dyfr lyriad ymlusgawl), Baldellia ranunculoides subsp. repens (Lam.) A. Löve \& D. Löve in Wales. In Leach, S. J. et al. (eds), Botanical Links in The Atlantic Arc. BSBI Conference Report No. 24: 311-319.

Kareiva, P., S. Watts, R. Mc Donald \& T. Boucher, 2007. Domesticated nature: shaping landscape and ecosystems for human welfare. Science 316: 1866-1869.

Kennedy, M. P. \& K. J. Murphy, 2004. Indicators of nitrate in wetland surfaces and soil-waters: interactions of vegetation and environmental factors. Hydrology and Earth System Sciences 8: 663-672.

Kozlowski, G. \& D. Matthies, 2009. Habitat differentiation in the aquatic plant genus Baldellia sp. (Alismataceae): implications for conservation. Aquatic Botany 90: 110-118.

Kozlowski, G., R. A. Jones \& F.-L. Vuille-Nicholls, 2008. Biological flora of the Central Europe: Baldellia ranunculoides (Alismataceae). Perspectives in Plant Ecology, Evolution and Systematics 10: 109-142.

Kozlowski, G., S. Rion, A. Python \& S. Riedo, 2009. Global conservation status assessment of the threatened aquatic plant genus Baldellia (Alismataceae): challenges and limitations. Biodiversity and Conservation 18: 23072325.

Malmquist, B. \& S. Rundle, 2002. Threats to the running water ecosystems of the world. Environmental Conservation 29: 134-153.

Meusel, H., E. Jäger \& E. Weinert, 1992. Vergleichende Chorologie der Zentraleuropäischen Flora, Vol. 1-3. Gustav Fischer, Jena.

Moser, D. M., A. Gygax, B. Bäumler, N. Wyler \& R. Palese, 2002. Liste Rouge des fougères et plantes à fleurs menacées de Suisse. BUWAL, Bern.

Pott, R., 1995. Die Pflanzengesellschaften Deutschlands, 2nd ed. Eugen Ulmer, Stuttgart.

Preston, C. D. \& J. M. Croft, 2001. Aquatic Plants in Britain and Ireland. Harley Books, Colchester, Essex.

Roelofs, J. G. M., 1983. Impact of acidification and eutrophication on macrophyte communities in soft waters in the Netherlands. I. Field observations. Aquatic Botany 17: 139-155.

Roelofs, J. G. M., J. A. A. R. Schuurkes \& A. J. M. Smits, 1984. Impact of acidification and eutrophication on macrophyte communities in soft waters in the Netherlands. II. Experimental studies. Aquatic Botany 18: 389-411.

Sala, O. E., F. S. Chapin III, J. J. Armesto, E. Berlow, J. Bloomfield, R. Dirzo, E. Huber-Sanwald, L. F. Huenneke, R. B. Jacson, A. Kinzig, R. Leemans, D. M. Lodge, H. A. Mooney, M. Oesterheld, N. LeRoy Poff, M. T. Sykes, B. H. Walker, M. Walker \& D. H. Wall, 2000. Global biodiversity scenarios for the year 2100. Science 287: 1770-1774.

Schaminée, J. H. J. \& G. H. P. Arts, 1992. Die Strandlinggesellschaften (Littorelletea Br.-Bl. et Tx. 43) der Niederlande, in europäischem Rahmen gefasst. Phytocoenologia 20: 529-558.

Schoof-van Pelt, M. M., 1973. Littorelletea - A Study of the Vegetation of Some Amphiphytic Communities of Western Europe. Stichting Studentenpers, Nijmegen.

Schubert, R., W. Hilbig \& S. Klotz, 1995. Bestimmungsbuch der Pflanzengesellschaften Mittel- und Nordostdeutschlands. Gustav Fischer, Stuttgart. 
Sculthorpe, C. D., 1967. The Biology of Aquatic Vascular Plants. Edward Arnold, London.

Smolders, A. J. P., E. C. H. E. T. Lucassen \& J. G. M. Roelofs, 2002. The isoetid environment: biogeochemistry and threats. Aquatic Botany 73: 325-350.

Szankowski, M. \& S. Klosowski, 2001. Habitat conditions of the phytocenoses dominated by Luronium natans (L.) Rafin. in Poland. Hydrobiologia 455: 213-222.

Thomas, J. D. \& P. W. G. Daldorph, 1994. The influence of nutrient and organic enrichment on a community dominated by macrophytes and gasteropod mollusks in a eutrophic drainage channel: relevance to snail control and conservation. Journal of Applied Ecology 31: 571-588.

Vuille, F.-L., 1988. The reproductive biology of the genus Baldellia (Alismataceae). Plant Systematics and Evolution 159: 173-183.

Willby, N. J. \& J. W. Eaton, 1993. The distribution, ecology and conservation of Luronium natans (L.) Raf. in Britain. Journal of Aquatic Plant Management 31: 70-76. 